\title{
PENGARUH PERSEPSI, SIKAP DAN PENGETAHUAN TERHADAP MINAT MENABUNG MASYARAKAT PADA BANK ACEH SYARIAH DI KOTA KUALA SIMPANG \\ ${ }^{1}$ Fuadi \\ ${ }^{2}$ Lidia Fitri \\ ${ }^{3} \mathrm{Al}$ Malikul Mulki \\ ${ }^{1}$ Islamic Economics Department, Faculty of Economics and Business, University of Malikussaleh ${ }^{2}$ Islamic Economics Department, Faculty of Economics and Business, University of Malikussaleh \\ ${ }^{3}$ Islamic Economics Department, Faculty of Economics and Business, University of Malikussaleh \\ $1_{\text {fuadi.msm@unimal.ac.id }}$ \\ lidia.fitri@unimal.ac.id \\ 3malikul.160440049@mhs.unimal.ac.id
}

\section{ARTICLE HISTORY}

Received:

17 April 2021

Revised

17 April 2021

Accepted:

19 April 2021

Online available:

20 Mei 2021

Keywords (Calibri10):

Perception, Attitudes, Knowledge and

Interest in Saving

*Correspondence: Name:

Al Malikul Mulki

E-mail:

malikul.160440049@mhs.unimal.ac.id

\begin{abstract}
This study examined the effect of perceptions, attitudes, and knowledge on interest in saving at Bank Aceh Syariah in the Kualasimpang city subdistrict. This study used primary data obtained by distributing questionnaires to 40 respondents selected using a Purposive Sampling technique. The data analysis method used was multiple linear regression with the help of SPSS. The results partially showed that perception (X1) positively and significantly influenced people's interest in saving at Bank Aceh Syariah in Kualasimpang city subdistrict $(Y)$ with a Sig value of 0.006, while attitude (X2) and knowledge (X3) positively but insignificantly influenced people's interest in saving at Bank Aceh Syariah in Kualasimpang city subdistrict $(Y)$ the Sig values are 0.068 and 0.194 respectively. Simultaneously, Perception (X1), Attitude (X2), and Knowledge (X3) positively and significantly influenced people's interest in saving at Bank Aceh Syariah in Kualasimpang city subdistrict (Y) with an F-count value of 10.482 and a Sig value of 0.000 .
\end{abstract}




\section{PENDAHULUAN}

Praktik Perbankan telah ada jauh sebelum adanya lembaga Perbankan seperti saat ini. Dalam sejarah islam, praktik kegiatan muamalah seperti menerima jasa titipan harta, memberi pinjaman uang untuk keperluan konsumsi atau untuk keperluan modal usaha, dan mengirimkan uang telah menjadi hal yang lazim dipraktekan oleh umat Islam sejak zaman Rasulullah SAW. Konsep teoritis tentang Bank Islam muncul pertama kali di Pakistan pada tahun 1940-an, dengan gagasan Perbankan yang berdasarkan prinsip bagi hasil. Di Indonesia perkembangan Bank Syariah dipelopori oleh PT Bank Muamalat Indonesia (BMI) yang sesuai akte pendiriannya berdiri pada tanggal 1 November 1991. Tercatat dalam Otoritas Jasa Keuangan (OJK) Syariah bahwa Perbankan Syariah memiliki jaringan sebanyak 1.868 Bank Umum Syariah (BUS), 347 Unit Usaha Syariah (UUS), serta 289 Bank Pembiayaan Rakyat Syariah (BPRS) pada tahun 2018 (OJK, 2017).

Sebagai daerah istimewa yang diberikan wewenang oleh pemerintah pusat dalam membuat peraturan daerahnya sendiri, pemerintah Provinsi Aceh mengeluarkan peraturan daerah Qanun Aceh tentang Lembaga Keuangan Syariah (LKS). Mengenai Lembaga Keuangan Syariah (LKS) Nomor 11 Tahun 2018, mengatur bahwa dalam waktu tiga tahun terhitung sejak tanggal Qanun LKS ditetapkan, seluruh lembaga keuangan yang beroperasi di Aceh akan dilaksanakan sesuai dengan prinsip Syariah. Salah satu Bank Umum Syariah (BUS) yang menjadi sorotan publik yaitu Bank Aceh Syariah. Selain sebagai Bank Umum Syariah, Bank Aceh Syariah merupakan Bank milik pemerintahan Provinsi Aceh. Sebelum dikeluarkannya Qanun Aceh No.11 tahun 2018, PT. Bank Aceh Syariah lebih dulu mengkonversikan dirinya ke Bank Syariah Pada tahun 2016. Semulanya Bank Aceh Syariah merupakan hasil konversi dari BPD Aceh, yang izin konversi tersebut ditetapkan berdasarkan Keputusan Dewan Komisioner OJK Nomor KEP. 44/D.03/2016 pada tanggal 1 September 2016. Konversi tersebut tidak hanya nama perusahaannya saja tetapi produk yang ada di Bank tersebut juga ikut dikonversikan.

Kecamatan Kota Kualasimpang Kabupaten Aceh Tamiang yang merupakan salah satu wilayah Provinsi Aceh yang juga akan menerapkan Qanun LKS, yang berarti setiap lembaga keuangan untuk kedepannya wajib dilaksanakan berdasarkan prinsip Syariah. Mayoritas masyarakatnya adalah muslim dengan jumlah penduduk 21094 jiwa (BPS Kabupaten Aceh Tamiang, 2019). Berdasarkan hasil observasi, sebagian masyarakat mengetahui Bank Syariah identik dengan Bank sistem bagi hasil dan tidak ada bunga. Selama ini Bank Aceh Syariah mendapatkan tempat yang cukup baik di mata masyarakat khususnya bagi pengguna jasa Bank Aceh Syariah, dikarenakan sebagai Bank milik pemerintah daerah, juga mempunyai peran penting dalam memajukan perekonomian daerah Provinsi Aceh. Namun pada kenyataannya yang kita temui masih banyak masyarakat yang belum sepenuhnya percaya terhadap Bank Aceh Syariah dan menganggap Bank Aceh Syariah sama masih dengan Bank konvensional. 


\section{TINJAUAN TEORITIS}

\section{Minat}

Minat (interest) dideskripsikan sebagai situasi seseorang sebelum melakukan suatu tindakan tertentu, yang dapat digunakan sebagai pertimbangan untuk memprediksi perilaku atau tindakan yang akan dipilih. Menurut Abdul Rahman Shaleh (2004) minat dapat diartikan sebagai perhatian, tindakan, kecenderungan, aktivitas atau situasi yang menarik, dan perasaan senang seseorang. Sedangkan menabung adalah suatu kegiatan perencanaan guna memenuhi suatu kebutuhan di masa yang akan datang yaitu jaminan akan materi. Jadi yang dimaksud minat menabung adalah suatu kekuatan yang mendorong seseorang untuk memberikan perhatiannya pada aktivitas menyimpan uang di Bank yang dilakukan dengan perasaan senang sehingga dapat memenuhi kebutuhan yaitu jaminan akan materi. Banyak hal yang bisa mempengaruhi minat menabung, diantaranya adalah persepsi, sikap dan pengetahuan dari seseorang. Menurut Kotler (2008), tahapan minat pembelian konsumen dapat diuraikan sebagai berikut:

\section{Perhatian (Attention)}

Tahap ini merupakan tahap pertama dalam menilai suatu produk atau jasa sesuai dengan kebutuhan calon pelanggan, selain itu calon pelanggan juga mempelajari produk atau jasa yang ditawarkan.

2. Tertarik (Interest)

Pada tahap ini, calon konsumen mulai tertarik untuk membeli produk atau jasa yang ditawarkan, setelah memperoleh informasi lebih detail tentang produk atau jasa yang ditawarkan.

3. Hasrat (Desire)Calon konsumen mulai memikirkan dan membahas produk atau jasa yang ditawarkan, karena keinginan untuk membeli dan keinginan untuk memiliki mulai timbul. Pada tahap ini, calon konsumen sudah mulai tertarik dengan produk yang ditawarkan. Dari tahapan ini adalah calon konsumen memiliki minat yang kuat untuk membeli dan menjual produk atau jasa yang diberikan.

4. Tindakan (Action)

ada tahap ini calon penggalan telah mempunyai kemantapan yang tinggi untuk membeli atau menggunakan produk atau jasa yang ditawarkan.

\section{Persepsi}

Persepsi adalah proses di mana seseorang mengatur dan menafsirkan kesan sensoriknya untuk memberi makna pada lingkungannya (Robbins, 2002). Persepsi adalah proses di mana sekelompok orang atau masyarakat menafsirkan kesan indranya yang diakhiri dengan pandangan atau pendapat, sehingga menimbulkan persepsi. Menurut Baba Ricardo (2012) dimensi yang berperan dalam membentuk persepsi yaitu: 
1. Pengetahuan tentang Bank Syariah (Knowledge of Islamic Banking), Dimensi ini menunjukkan pengetahuan tentang Perbankan Syariah, termasuk reputasi Bank Syariah, prinsip operasi Bank Syariah dan Bank Syariah hanya untuk umat muslim.

2. Kepercayaan terhadap Bank Syariah (Confidence in Islamic Banking), dimensi ini menunjukkan tentang suatu keyakinan terhadap Bank Syariah bahwa menabung di Bank Syariah lebih aman, berinvestasi di Bank Syariah kurang beresiko serta Bank Syariah bisa bersaing dengan Bank konvensional.

3. Produk dan layanan Bank Syariah (Islamic Banking product and services), dimensi ini menunjukkan bahwa Bank Syariah memberikan pelayanan yang cepat dan efisien, staf Bank Syariah sopan dan ramah serta Bank Syariah menyediakan berbagai macam produk dan layanan.

\section{Sikap}

Sikap adalah ungkapan perasaan dari dalam diri seseorang, mengungkapkan senang atau tidaknya seseorang, suka atau tidak suka, dan setuju atau tidak setuju terhadap suatu objek (Schiffman dan Kanuk, 2007). Sikap merupakan faktor terpenting dalam minat menabung. Masyarakat memiliki atau tidak memiliki minat dalam menabung dapat dipengaruhi oleh sikap masyarakat terhadap karakteristik Bank Syariah itu sendiri. Untuk melihat sejauh mana sikap berpengaruh terhadap minat nasabah menggunakan produk Bank Syariah maka diperlukan indikator untuk mengukurnya. Adapun indikator sikap sebagai berikut (Setiadi, 2003)):

1. Alasan yang mendorong konsumen untuk menabung di Bank Syariah.

2. Sikap konsumen apabila Bank Syariah membuka cabang yang tersebar di seluruh negeri.

3. Sikap konsumen apabila diumumkan bahwa menabung di Bank Syariah tidak akan mendapatkan Riba.

4. Sikap konsumen terhadap Bank Syariah yang meminjamkan modal tanpa bunga sebagai suatu kontribusi pihak Bank dalam membantu masyarakat.

5. Sikap konsumen tentang penghapusan tingkat bunga pada pinjaman pada prinsip bagi hasil di Bank Syariah.

\section{Pengetahuan}

Faktor lain yang mempengaruhi minat menabung di Bank Syariah adalah pengetahuan tentang Bank Syariah. Menurut (Kamus Besar Bahasa Indonesia) Pengetahuan berarti segala sesuatu yang diketahui atau segala sesuatu yang diketahui berkenaan dengan suatu hal. Menurut Notoatmojo (2007), pengetahuan atau kognitif merupakan domain yang sangat penting untuk terbentuknya tindakan seseorang (overt behaviour). Pengetahuan adalah sebagai suatu pembentukan yang secara terus menerus oleh seseorang yang setiap saat megalami reorganisasi karena adanya pemahaman-pemahaman baru (S Arikunto, 1994). Sedangakan menurut Mowen 
\& Minor (2001) Pengetahuan adalah "The amount of experience with and information about particular products or services person has.".atau pengetahuan adalah sejumlah pengalaman dengan berbagai macam informasi tentang produk atau jasa tertentu yang dimiliki. Untuk melihat sejauh mana pengetahuan berpengaruh terhadap keputusan nasabah menggunakan produk Bank Syariah maka diperlukan indikator untuk mengukurnya (Sumarwan, 2011). Adapun indikator pengetahuan sebagai berikut:

1. Pengetahuan Produk

Pengetahuan produk merupakan kumpulan berbagai macam informasi mengenai produk, merek, terminologi produk, atribut atau fitur produk, harga produk, dan kepercayaan mengenai produk.

2. Pengetahuan Pembelian

Pengetahuan pembelian terdiri atas pengetahuan tentang toko, lokasi produk di dalam toko tersebut dan penempatan produk yang sebenarnya di dalam toko tersebut.

3. Pengetahuan Pemakaian

Pengetahuan pemakaian di mana suatu produk akan memberikan manfaat jika produk tersebut telah digunakan atau dikonsumsi oleh konsumen.

\section{Penelitian Terdahulu}

Wijayati (2019) “Pengaruh Persepsi Dan Pengetahuan Terhadap Minat Menabung Di Bank Syariah Pada Masyarakat Dukuh Krajan Pulosari Jambon Ponorogo". Penelitian ini menggunakan Metode Kuantitatif dengan menggunakan analisis Regresi Linear Sederhana dan Linear Berganda. Hasil penelitian ini menunjukkan bahwa: Persepsi berpengaruh secara Signifikan terhadap minat menabung di Bank Syariah yang dibuktikan dengan nilai Sig 0,002 < 0,05 (2) pengetahuan berpengaruh secara Signifikan terhadap minat menabung di Bank Syariah yang dibuktikan dengan nilai Sig $0,000<0,05$ (3) Secara simultan persepsi dan pengetahuan berpengaruh secara Signifikan terhadap minat menabung di Bank Syariah yang dibuktikan dengan nilai Sig 0,000< 0,05 .

Ninuk Arifah (2018) "Pengaruh Pengetahuan, Kepercayaan Dan Sikap Anggota Terhadap Keputusan Menabung Di Bmt (Studi Kasus Di Bmt Syamil Ampel Boyolali)". Penelitian ini menggunakan Metode Kuantitatif dengan menggunakan analisis Regresi Linear Berganda. Dari hasil penelitian ini dapat disimpulkan berdasarkan Uji t, variabel pengetahuan (X1), Sikap (X3) berpengaruh terhadap keputusan menabung di BMT Syamil Ampel Boyolali (Y), sedangkan variabel kepercayaan (X2) tidak berpengaruh terhadap keputusan menabung di BMT Syamil Ampel Boyolali (Y).

Hikmah Ramadani (2018) "Analisis Pengaruh Pengetahuan, Sikap Dan Lingkungan Sosial Terhadap Keputusan Nasabah Menggunakan Produk Bank Syariah (Studi Kasus Bank BRI Syariah KCP Magelang)". Metode yang digunakan ialah metode kuantitatif dengan teknik Analisis Regresi Linear Berganda. Berdasarkan hasil uji $\mathrm{t}$ test menunjukkan bahwa variabel pengetahuan mempunyai pengaruh positif dan Signifikan terhadap keputusan nasabah, variabel sikap 
berpengaruh positif dan Signifikan terhadap keputusan nasabah dan variabel lingkungan sosial berpengaruh positif dan Signifikan terhadap keputusan nasabah. Hasil uji $F$ test menunjukkan bahwa pengetahuan, sikap dan lingkungan sosial secara bersama-sama berpengaruh terhadap keputusan nasabah.

Agus Arwani (2015) "Pengaruh Sikap Mahasiswa Muslim Terhadap Minat Pada Bank Syariah". Metode Kuantitatif dengan menggunakan analisis Regresi Linear Sederhana dan Linear Berganda. Hasil penelitian diperoleh bahwa nilai koefisien regresi variabel sikap dan norma subyektif adalah Signifikan, dan variabel sikap dengan minat dan juga antara variabel norma subyektif dengan minat, masing-masing hubungan tersebut mempunyai tingkat keeratan yang cukup tinggi. Hal ini berarti bahwa semua variabel bebas mempunyai hubungan positif dengan variabel tidak bebasnya.

Ainun Mardiah, Agung Pradhana Putra, Junaidi (2017) "Analisis Minat Masyarakat Menabung Di Bank Syariah (Studi Kasus Di Kampung Paya Bedi Aceh Tamiang)". Metode Kuantitatif dengan menggunakan analisis Regresi Linear Berganda. Hasil penelitian juga menunjukkan secara parsial bahwa (1) terdapat pengaruh yang Signifikan faktor pelayanan terhadap minat menabung masyarakat Kampung Paya Bedi di Bank Syariah Kota Kualasimpang; (2) terdapat pengaruh yang tidak Signifikan faktor produk terhadap minat menabung masyarakat Kampung Paya Bedi di Bank Syariah Kota Kualasimpang.

\section{Hipotesis Penelitian}

Hipotesis merupakan jawaban sementara terhadap rumusan masalah penelitian, di mana rumusan masalah penelitian telah dinyatakan dalam kalimat pernyataan (Sugiyono, 2012). Berdasarkan perumusan masalah dan kajian teoritis maupun empiris maka hipotesis dalam penelitian ini adalah:

H1 : Diduga persepsi mempengaruhi minat menabung masyarakat pada Bank Aceh Syariah di Kecamatan Kota Kualasimpang.

H1 : Diduga persepsi mempengaruhi minat menabung masyarakat pada Bank Aceh Syariah di Kecamatan Kota Kualasimpang.

H2 : Diduga sikap mempengaruhi minat menabung masyarakat pada Bank Aceh Syariah di Kecamatan Kota Kualasimpang.

H3: Diduga pengetahuan mempengaruhi minat menabung masyarakat pada Bank Aceh Syariah di Kecamatan Kota Kualasimpang.

H4 : Diduga persepsi, sikap dan pengetahuan secara bersama-sama mempengaruhi minat menabung masyarakat pada Bank Aceh Syariah di Kecamatan Kota Kualasimpang.

\section{METODOLOGI PENELITIAN}

\section{Desain Penelitian}


Dalam penelitian ini, jenis penelitian yang digunakan adalah Penelitian Lapangan (Field Research) dengan menggunakan metode kuantitatif yaitu menganalisis data berupa angka-angka yang dapat dihitung terkait dengan masalah yang akan diteliti. Untuk memperoleh data dan informasi yang sesuai dengan objek penelitian ini, penulis menggunakan kuesioner (angket) untuk pengumpulan data. Adapun mekanismenya yaitu memberikan kuesioner secara langsung bertemu dengan responden dan secara tidak langsung dengan mengisi Google Form yang dapat diakses oleh responden melalui link https://forms.gle/EwTimmV8rqxvQQbg7.

Dalam penelitian ini, peneliti peneliti menggunakan teknik Non-Probability Sampling melalui Purposive Sampling. Purposive Sampling merupakan teknik pengambilan sampel dengan pertimbangan tertentu (Sugiyono, 2011).

Menurut Roscoe dalam Sugiyono (2010) memberikan saran tentang ukuran sampel penelitian, seperti:

a. Ukuran sampel yang layak dalam penelitian adalah antara 30 sampai dengan 500 .

b. Jika sampel dibagi menjadi beberapa kategori (misal: laki-laki/perempuan, pegawai negeri/swasta dan lain-lain) maka jumlah sampel anggota untuk setiap kategori minimal 30.

c. Bila dalam penelitian akan melakukan analisis dengan multivariate (korelasi atau regresi ganda misalnya), maka jumlah anggota sampel minimal 10 kali dari jumlah variabel yang diteliti. Misalnya variabel penelitiannya ada 5 (independen + dependen), maka jumlah anggota sampel $=10 \times 5=50$.

Berdasarkan beberapa pendapat diatas karena dalam penelitian ini terdiri dari empat variabel yaitu tiga variabel bebas dan satu variabel terikat maka sampel minimal yang harus dikenai yaitu 40 responden.

\section{Lokasi dan Objek Penelitian}

Dalam penelitian ini yang menjadi objek penelitian adalah seluruh masyarakat Kecamatan Kota Kualasimpang yang memiliki rekening tabungan di Bank Aceh Syariah. Adapun yang menjadi tempat sebagai lokasi penelitian ini adalah Kecamatan Kota Kualasimpang Kabupaten Aceh Tamiang Provinsi Aceh.

\section{Tehnik Analisis Data}

Analisis data yang digunakan dalam penelitian ini adalah analisis kuantitatif dengan persamaan regresi linear berganda. Model persamaan regresi linier berganda dengan rumus sebagai berikut:

$$
Y=\alpha+\beta 1 \times 1+\beta 2 \times 2++\beta 3 \times 3+e
$$

$\mathrm{Y}=$ Minat menabung 


$$
\begin{aligned}
& \alpha=\text { Nilai konstan } \\
& X 1=\text { Persepsi } \\
& X 2=\text { Sikap } \\
& X 3=\text { Pengetahuan } \\
& \beta 1, \beta 2, \beta 3=\text { Koefisien regresi } \\
& \text { e }=\text { Standard error }
\end{aligned}
$$

\section{HASIL DAN PEMBAHASAN}

\section{Uji Validitas}

Uji validitas dilakukan untuk menguji kelayakan kuesioner atau mengukur sah atau valid tidaknya suatu kuesioner. Pengujian validitas pada penelitian ini dilakukan dengan membandingkan nilai $r_{\text {hitung }}$ dengan $r_{\text {tabel }}$ untuk degree of freedom (df) $=n-2$, dalam hal ini $n$ adalah jumlah sampel. Jika $r_{\text {hitung }}$ lebih besar dari $r_{\text {tabel }}$ dan nilai positif maka pertanyaan atau indikator tersebut dinyatakan valid, tetapi jika $r_{\text {hitung }}$ lebih kecil daripada $r_{\text {tabel }}$ maka pertanyaan atau indikator tersebut tidak valid (Ghozali, 2016). Diketahui jumlah sampel dalam penelitian ini 40 , untuk menentukan maka menggunakan rumus degree of freedom (df) $=n-2,40-2=38, r_{\text {tabel }}$ 38 adalah $0,312$. 
Tabel 1

Hasil Uji Validitas

Correlations

\begin{tabular}{|c|c|c|c|c|c|}
\hline & & X1p1 & X1p2 & $1 p 3$ & Persepsi(X1) \\
\hline \multirow{3}{*}{ X1p1 } & Pearson Correlation & 1 & ,699** & $656^{* *}$ & $908^{* *}$ \\
\hline & Sig. (2-tailed) & & ,000 & ,000 & ,000 \\
\hline & $\mathrm{N}$ & 40 & 40 & 40 & 40 \\
\hline \multirow{3}{*}{ X1p2 } & Pearson Correlation & ,699** & 1 &, $551^{* *}$ & $849^{* *}$ \\
\hline & Sig. (2-tailed) & ,000 & & ,000 & ,000 \\
\hline & $\mathrm{N}$ & 40 & 40 & 40 & 40 \\
\hline \multirow{3}{*}{ X1p3 } & Pearson Correlation & $656^{* *}$ &, $551^{* *}$ & 1 & $852^{* *}$ \\
\hline & Sig. (2-tailed) & ,000 & ,000 & & ,000 \\
\hline & $\mathrm{N}$ & 40 & 40 & 40 & 40 \\
\hline \multirow{3}{*}{ Persepsi(X1) } & Pearson Correlation & $908^{* *}$ & $849^{* *}$ & $852^{* *}$ & 1 \\
\hline & Sig. (2-tailed) & ,000 & ,000 & ,000 & \\
\hline & $\mathrm{N}$ & 40 & 40 & 40 & 40 \\
\hline
\end{tabular}

**. Correlation is Significant at the 0.01 level (2-tailed).

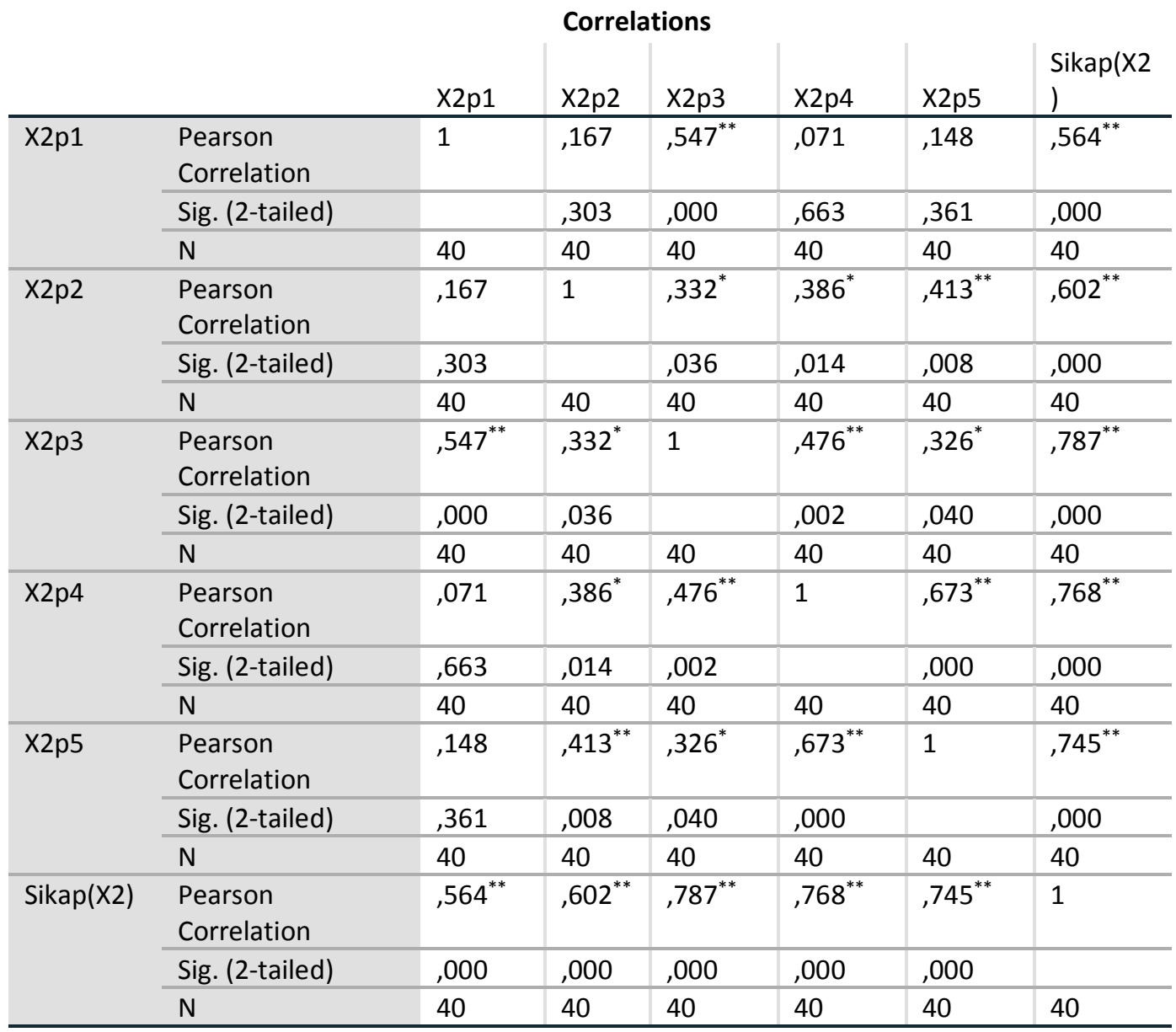

**. Correlation is Significant at the 0.01 level (2-tailed).

*. Correlation is Significant at the 0.05 level (2-tailed). 


\begin{tabular}{|c|c|c|c|c|c|}
\hline \multicolumn{6}{|c|}{ Correlations } \\
\hline & & X3p1 & X3p2 & X3p3 & $\begin{array}{l}\text { Pengetahuan( } \\
\text { X3) }\end{array}$ \\
\hline \multirow[t]{3}{*}{ X3p1 } & Pearson Correlation & 1 &, $788^{* *}$ &, $610^{* *}$ & $904^{* *}$ \\
\hline & Sig. (2-tailed) & & ,000 & ,000 & ,000 \\
\hline & $\mathrm{N}$ & 40 & 40 & 40 & 40 \\
\hline \multirow[t]{3}{*}{ X3p2 } & Pearson Correlation &, $788^{* *}$ & 1 &, $565^{* *}$ & $875^{* *}$ \\
\hline & Sig. (2-tailed) & ,000 & & ,000 & ,000 \\
\hline & $\mathrm{N}$ & 40 & 40 & 40 & 40 \\
\hline \multirow[t]{3}{*}{ X3p3 } & Pearson Correlation & $610^{* *}$ &, $565^{* *}$ & 1 & $850^{* *}$ \\
\hline & Sig. (2-tailed) &, 000 & ,000 & &, 000 \\
\hline & $\mathrm{N}$ & 40 & 40 & 40 & 40 \\
\hline \multirow[t]{3}{*}{ Pengetahuan(X3) } & Pearson Correlation &, $904^{* *}$ & $875^{* *}$ & $850^{* *}$ & 1 \\
\hline & Sig. (2-tailed) & ,000 & ,000 & ,000 & \\
\hline & $\mathrm{N}$ & 40 & 40 & 40 & 40 \\
\hline
\end{tabular}

**. Correlation is Significant at the 0.01 level (2-tailed).

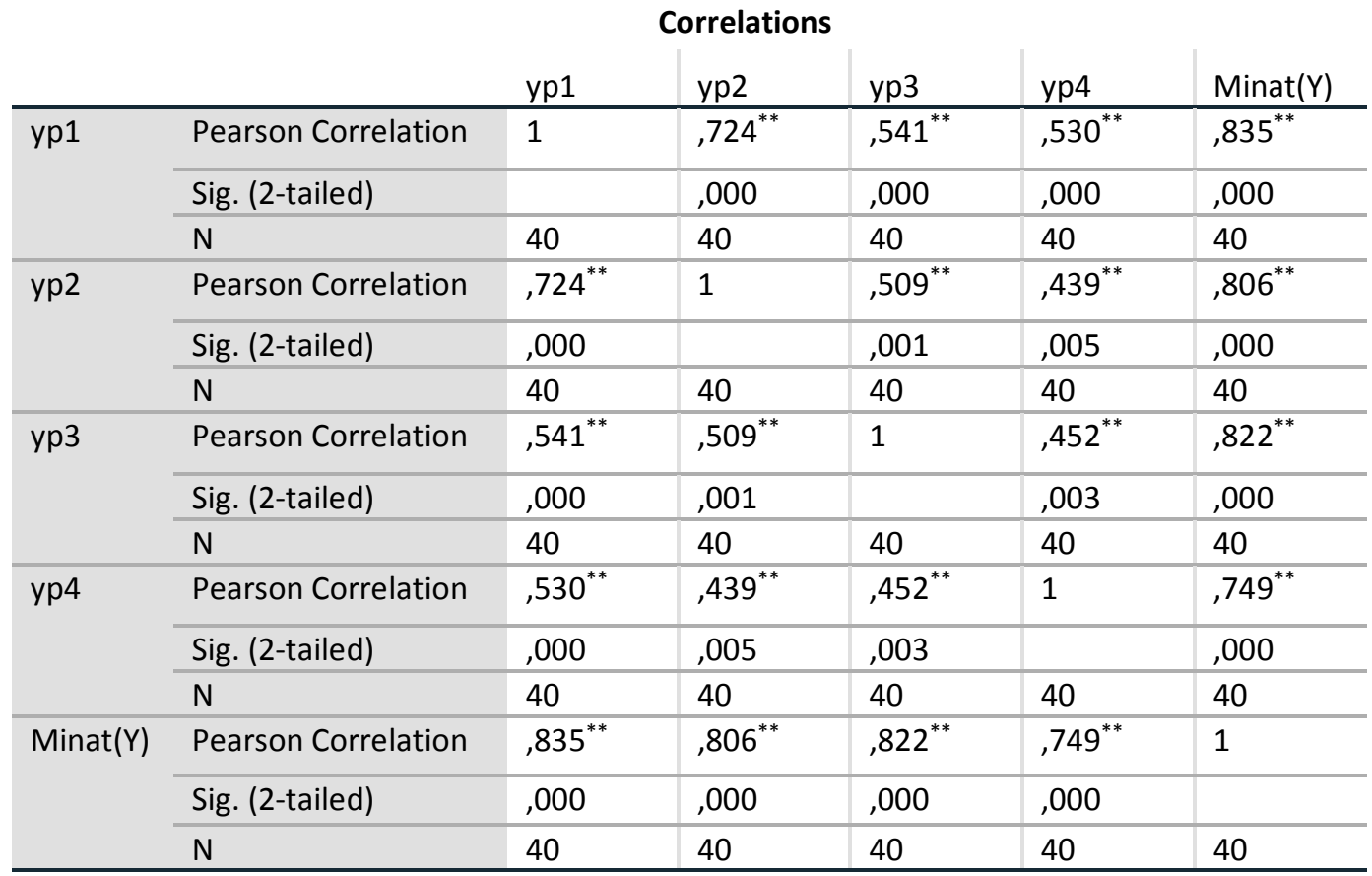

**. Correlation is Significant at the 0.01 level (2-tailed).

Sumber Data Diolah: SPSS 25

Berdasarkan tabel di atas maka dapat dijelaskan item yang terdapat pada kuesioner

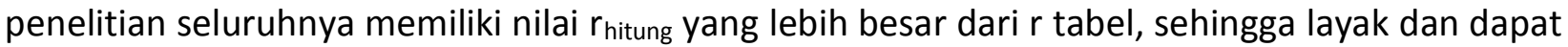
digunakan sebagai alat untuk memperoleh data penelitian. 


\section{Uji Reliabilitas}

Untuk menentukan apakah suatu instrumen penelitian reliabel atau tidak maka teknik yang dapat digunakan adalah teknik Alpha Cronbach. Kriteria suatu instrumen penelitian dikatakan reliabel dengan menggunakan Alpha Cronbach apabila koefisien reliabilitas > 0,60 (Ghozali, 2011). Untuk mengetahui hasil uji reliabilitas dalam penelitian ini dapat dilihat dari tabel dibawah ini:

Tabel 2

Hasil Uji Reliabilitas

Persepsi (X1)

Reliability Statistics

Cronbach's

Alpha $\quad \mathrm{N}$ of Items

\begin{tabular}{r|r}
\multicolumn{1}{c|}{ Alpha } & N of Items \\
\hline, 838 & 3 \\
\hline
\end{tabular}

Sikap (X2)

Reliability Statistics

Cronbach's

\begin{tabular}{r|r}
\multicolumn{1}{c|}{ Alpha } & N of Items \\
\hline, 731 & 5 \\
\hline
\end{tabular}

Pengetahuan (X3)

Reliability Statistics

Cronbach's

Alpha N of Items

\begin{tabular}{r|r}
\multicolumn{1}{c|}{ Alpha } & N of Items \\
\hline, 840 & 3 \\
\hline
\end{tabular}

Minat $(Y)$

Reliability Statistics

Cronbach's

Alpha N of Items

Sumber Data Diolah: SPSS 25

\begin{tabular}{r|r}
\multicolumn{1}{c|}{ Alpha } & N of Items \\
\hline, 798 & 4 \\
\hline
\end{tabular}

Berdasarkan tabel di atas, variabel Persepsi (X1), Sikap (X2), Pengetahuan (X3), dan Minat menabung $(\mathrm{Y})$ menunjukkan nilai Alpha Cronbach $>0.60$ yang berarti semua variabel reliabel. Hal ini menunjukkan bahwa item pertanyaan yang digunakan mampu memperoleh data yang konsisten dalam arti jika pertanyaan tersebut diajukan kembali akan diperoleh jawaban yang relatif sama.

\section{Pengujian Asumsi Klasik}

\section{- Uji normalitas}

Uji normalitas sampel atau menguji normal atau tidaknya sampel, tidak lain sebenarnya adalah mengadakan pengujian terhadap normal tidaknya sebaran data yang akan dianalisis (Arikunto, 2005). Langkah yang dilakukan dalam uji normalitas adalah dengan menggunakan One- 
Sample Kolmogorov-Smirnov dengan menggunakan taraf Signifikan 0,05. Data dinyatakan berdistribusi normal jika taraf Signifikansi > 0,05 (Priyatno, 2008)

Tabel 3

Hasil Uji Normalitas

One-Sample Kolmogorov-Smirnov Test

\begin{tabular}{lll} 
& & \multicolumn{1}{c}{$\begin{array}{l}\text { Unstandardized } \\
\text { Residual }\end{array}$} \\
\hline $\mathrm{N}$ & & 40 \\
\hline Normal & Mean &, 0000000 \\
Parameters & & 1,81953792 \\
\hline Most Extreme & Std. Deviation &, 072 \\
\cline { 2 - 3 } Differences & Absolute &, 063 \\
\cline { 2 - 3 } & Positive &,- 072 \\
\hline Test Statistic & Negative &, 072 \\
\hline Asymp. Sig. (2-tailed) & &, $200^{\mathrm{c}, \mathrm{d}}$ \\
\hline
\end{tabular}

a. Test distribution is Normal.

b. Calculated from data.

c. Lilliefors Significance Correction.

d. This is a lower bound of the true Significance.

Sumber Data Diolah: SPSS 25

Berdasarkan Tabel 4.15 di atas menunjukkan bahwa dalam penelitian ini data berdistribusi normal karena hasil uji normalitas menggunakan One-Sample Kolmogorov-Smirnov Test memiliki tingkat Signifikan sebesar 0,200 >0,05. Nilai tersebut dapat dilihat dari Asymp.Sig. (2-tailed) di kolom Unstandardized Residual.

\section{- Uji Multikolinearitas}

Uji Multikolinearitas bertujuan untuk menguji apakah model regresi ditemukan adanya korelasi antar variabel independen (Ghozali, 2018). Model regresi yang baik seharusnya tidak memiliki korelasi antar variabel independen. Dari VIF (Variance Inflation Factor) dan TOL (Tolerance), dapat dilihat apakah terdapat multikolinearitas dalam model regresi.Regresi bebas dari masalah multikolinearitas jika nilai VIF $<10$ dan nilai TOL $>0,10$.

Tabel 4 Hasil Uji Multikolinearitas

Coefficients $^{\mathrm{a}}$

\begin{tabular}{llrr} 
& & \multicolumn{2}{c}{ Collinearity Statistics } \\
\multirow{2}{*}{ Model } & & Tolerance & \multicolumn{1}{c}{ VIF } \\
\hline \multirow{2}{*}{1} & Persepsi(X1) &, 690 & 1,449 \\
\cline { 2 - 4 } & Sikap(X2) &, 796 & 1,256 \\
\cline { 2 - 4 } & Pengetahuan(X3) &, 801 & 1,248 \\
\hline
\end{tabular}

a. Dependent Variable: Minat(Y)

Sumber Data Diolah: SPSS 25

Dari hasil pengujian di atas dapat dilihat bahwa masing-masing variabel independen mempunyai nilai VIF $<10$, dan nilai Tolerance $>0,10$. Sehingga model regresi dalam penelitian ini 
tidak terjadi multikolinieritas. Dengan demikian dapat disimpulkan bahwa model regresi ini telah memenuhi syarat analisis regresi.

\section{Uji Heteroskedastisitas}

Uji heteroskedastisitas dilakukan untuk menguji apakah ada pengaruh Residual statistik terhadap model regresi. Model regresi yang baik adalah model yang Residual statistiknya tidak menggangu model regresi (homoskedastis). Uji heteroskedastisitas dilakukan dengan uji Glejser, yakni dengan meregresikan nilai absolut Residual regresi dengan variabel independen. Model regresi telah memenuhi asumsi heteroskedastisitas jika nilai Signifikansi pengaruh variabel bebas dengan nilai Absolute Residual statistik lebih dari 0,05.

Tabel 5

Hasil Uji Heteroskedastisitas

Coefficients $^{\mathrm{a}}$

\begin{tabular}{|c|c|c|c|c|c|c|}
\hline & \multirow[b]{2}{*}{ Model } & \multicolumn{2}{|c|}{$\begin{array}{l}\text { Unstandardized } \\
\text { Coefficients }\end{array}$} & \multirow{2}{*}{$\begin{array}{c}\text { Standardized } \\
\text { Coefficients } \\
\text { Beta }\end{array}$} & \multirow[b]{2}{*}{$\mathrm{T}$} & \multirow[b]{2}{*}{ Sig. } \\
\hline & & $\mathrm{B}$ & Std. Error & & & \\
\hline \multirow[t]{3}{*}{1} & (Constant) & ,787 & 1,576 & & ,499 & ,621 \\
\hline & Persepsi(X1) & ,058 & 118 & ,097 & ,489 & ,628 \\
\hline & Sikap(X2) &,- 016 & ,074 &,- 040 &,- 214 & ,832 \\
\hline
\end{tabular}

a. Dependent Variable: ABRESID

Sumber Data Diolah: SPSS 25

Berdasarkan Tabel 4.17 dapat diketahui bahwa, untuk variabel persepsi nilai Sig. sebesar $0,62>0,05$, variabel sikap diperoleh nilai sebesar 0,628 >0,05 dan variabel pengetahuan diperoleh nilai sebesar $0,832>0,05$, maka dapat disimpulkan tidak terjadi masalah heteroskedastisitas.

\section{Uji Regresi Linear Berganda}

Analisis data yang digunakan dalam penelitian ini adalah analisis kuantitatif dengan persamaan regresi linear berganda. Berikut ini adalah hasil uji regresi linier berganda:

\section{Tabel 6}

Hasil Uji Regresi Linear Berganda

Coefficients $^{\mathrm{a}}$

\begin{tabular}{|c|c|c|c|c|c|c|}
\hline & & \multicolumn{2}{|c|}{$\begin{array}{l}\text { Unstandardized } \\
\text { Coefficients }\end{array}$} & \multirow{2}{*}{$\begin{array}{l}\text { Standardized } \\
\text { Coefficients } \\
\text { Beta }\end{array}$} & \multirow[b]{2}{*}{$\mathrm{t}$} & \multirow[b]{2}{*}{ Sig. } \\
\hline \multicolumn{2}{|c|}{ Model } & $\mathrm{B}$ & Std. Error & & & \\
\hline \multirow[t]{4}{*}{1} & (Constant) & 1,926 & 2,605 & & ,739 & ,465 \\
\hline & Persepsi(X1) &, 566 & 196 & ,424 & 2,892 & ,006 \\
\hline & Sikap(X2) & 229 & 122 & ,257 & 1,881 & ,068 \\
\hline & Pengetahuan(X3) & ,200 & 151 & ,180 & 1,323 & 194 \\
\hline
\end{tabular}

a. Dependent Variable: Minat(Y)

Sumber Data Diolah: SPSS 25 
Dari hasil uji regresi linier berganda pada Tabel 4.18, dapat dirumuskan persamaan regresi seperti berikut ini:

$$
Y=1,926+0,566 \times 1+0,229 \times 2+0,200 \times 3+e
$$

Penjabaran dari model regresi yang telah disusun di atas antara lain adalah sebagai berikut:

1. Nilai konstanta $(\alpha)$ dalam model regresi ini adalah sebesar 1,926 . Nilai ini menunjukkan bahwa, jika variabel-variabel persepsi, sikap dan pengetahuan masyarakat bernilai 0 maka nilai minat menabung masyarakat pada Bank Aceh Syariah di Kecamatan Kota Kualasimpang adalah sebesar 1,921.

2. Nilai koefisien regresi persepsi (X1) dalam model regresi ini adalah sebesar 0,566. Artinya jika variabel persepsi (X1) meningkat sebesar 1\% dengan asumsi Variabel sikap (X2) dan pengetahuan (X3) dan konstanta $(\alpha)$ adalah 0 (nol), maka minat menabung meningkat sebanyak 0,566. Hal tersebut menunjukkan bahwa variabel persepsi (X1) berkontribusi positif bagi minat menabung masyarakat, sehingga makin bagus persepsi makin tinggi pula minat menabung masyarakat pada Bank Aceh Syariah di Kecamatan Kota Kualasimpang.

3. Nilai koefisien regresi sikap (X2) dalam model regresi ini adalah sebesar 0,229 . Artinya jika variabel sikap (X2) meningkat sebesar 1\% dengan asumsi Variabel persepsi (X1) dan pengetahuan (X3) dan konstanta ( $\alpha$ ) adalah 0 (nol), maka minat menabung meningkat sebanyak 0,229 . Hal tersebut menunjukkan bahwa variabel sikap (X2) berkontribusi positif terhadap minat menabung, sehingga semakin baik sikap semakin tinggi pula minat menabung masyarakat pada Bank Aceh Syariah di Kecamatan Kota Kualasimpang.

4. Nilai koefisien regresi pengetahuan (X3) dalam model regresi ini adalah sebesar 0,200. Artinya jika variabel pengetahuan (X3) meningkat sebesar $1 \%$ dengan asumsi Variabel persepsi (X1) dan sikap (X2) dan konstanta ( $\alpha$ ) adalah 0 (nol), maka minat menabung meningkat sebanyak 0,200 . Hal tersebut menunjukkan bahwa variabel pengetahuan (X3) berkontribusi positif terhadap minat menabung, sehingga semakin bagus pengetahuan semakin tinggi pula minat menabung masyarakat pada Bank Aceh Syariah di Kecamatan Kota Kualasimpang.

\section{Pengujian Hipotesis Hasil Uji t (Parsial)}

Uji t dilakukan untuk menguji pengaruh parsial masing-masing variabel independen terhadap variabel dependen. Uji t dilakukan dengan membandingkan antara $t_{\text {hitung }}$ dengan $t_{\text {tabel, }}$ pada taraf Sig. 0,05 (5\%) dengan kriteria apabila thitung $>t_{\text {tabel }}$ maka H1 diterima, sedangkan jika $t_{\text {hitung }}<\mathrm{t}_{\text {tabel }}$ maka $\mathrm{H} 1$ ditolak. 


\begin{tabular}{|c|c|c|c|c|c|c|}
\hline \multicolumn{7}{|c|}{ Coefficients $^{a}$} \\
\hline \multirow[b]{2}{*}{ Model } & & \multicolumn{2}{|c|}{$\begin{array}{l}\text { Unstandardized } \\
\text { Coefficients }\end{array}$} & \multirow{2}{*}{$\begin{array}{l}\text { Standardized } \\
\text { Coefficients } \\
\text { Beta }\end{array}$} & \multirow[b]{2}{*}{$\mathrm{T}$} & \multirow[b]{2}{*}{ Sig. } \\
\hline & & $\mathrm{B}$ & Std. Error & & & \\
\hline \multirow[t]{4}{*}{1} & (Constant) & 1,926 & 2,605 & & 739 & ,465 \\
\hline & Persepsi(X1) & ,566 & 196 & ,424 & 2,892 & ,006 \\
\hline & Sikap(X2) & ,229 & 122 & ,257 & 1,881 & ,068 \\
\hline & Pengetahuan(X3) & ,200 & ,151 & , 180 & 1,323 & ,194 \\
\hline
\end{tabular}

a. Dependent Variable: Minat( $\mathrm{Y})$

Sumber Data Diolah: SPSS 25

Adapun nilai $t_{\text {tabel }}$ dapat dicari menggunakan rumus $\mathrm{t}=(\alpha / 2 ; \mathrm{n}-\mathrm{k})=\mathrm{t}(0,05 / 2 ; 40-4)=\mathrm{t}$ $(0,025 ; 36)=2,028$. Hasil pengujian $t$ akan dijelaskan sebagai berikut:

1. Variabel Persepsi (X1)

Hasil uji t pada variabel Variabel Persepsi (X1) mempunyai thitung $>t_{\text {tabel }}(2,822>2,028)$ dan nilai Sig 0,006 < 0,05. Berarti, maka HO ditolak dan H1 diterima. Artinya, persepsi berpengaruh positif dan Signifikan terhadap minat menabung masyarakat pada Bank Aceh Syariah di Kecamatan Kota Kualasimpang. Sehingga hipotesis pertama dapat diterima.

2. Variabel Sikap (X2)

Hasil uji t pada variabel sikap (X2) mempunyai $t_{\text {hitung }}<t_{\text {tabel }}(1,881<2,028)$ dan nilai Sig $0,068>0,05$. Berarti nilai $t_{\text {hitung }}$ lebih kecil dari $t_{\text {tabel, }}$ maka $\mathrm{H} 2$ ditolak dan HO diterima. Artinya, sikap berpengaruh positif tetapi tidak Signifikan terhadap minat menabung masyarakat pada Bank Aceh Syariah di Kecamatan Kota Kualasimpang. Sehingga hipotesis kedua ditolak.

3. Variabel Pengetahuan (X3)

Hasil uji t pada pengetahuan (X3) mempunyai $t_{\text {hitung }}<t_{\text {tabel }}(1,323<2,028)$ dan nilai Sig $0,194>0,05$. Berarti nilai $t_{\text {hitung }}$ lebih kecil dari $t_{\text {tabel, }}$ maka H3 ditolak dan HO diterima. Artinya, pengetahuan berpengaruh positif tetapi tidak Signifikan terhadap minat menabung masyarakat pada Bank Aceh Syariah di Kecamatan Kota Kualasimpang. Sehingga hipotesis ketiga ditolak.

\section{Uji F (simultan)}

Uji F ini dilakukan untuk mengetahui pengaruh variabel bebas terhadap variabel terikat secara simultan atau keseluruhan. Untuk mengetahuinya dapat dilihat dengan cara

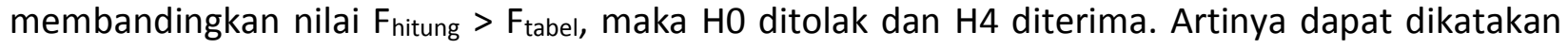
bahwa variabel-variabel independen berpengaruh secara bersama-sama terhadap variabel dependen. 


\begin{tabular}{|c|c|c|c|c|c|c|}
\hline \multicolumn{2}{|c|}{ Model } & $\begin{array}{l}\text { Sum of } \\
\text { Squares }\end{array}$ & Df & Mean Square & $\mathrm{F}$ & Sig. \\
\hline \multirow[t]{3}{*}{1} & Regression & 112,782 & 3 & 37,594 & 10,482 &, $000^{b}$ \\
\hline & Residual & 129,118 & 36 & 3,587 & & \\
\hline & Total & 241,900 & 39 & & & \\
\hline
\end{tabular}

a. Dependent Variable: Minat(Y)

b. Predictors: (Constant), Pengetahuan(X3), Sikap(X2), Persepsi(X1)

Sumber Data Diolah: SPSS 25

Untuk melihat nilai $F_{\text {tabel }}$ yaitu dengan menentukan nilai derajat bebas ( $\mathrm{df} 1$ ) dengan rumus $\mathrm{df1}=\mathrm{k}-1$.Kemudian menentukan derajat bebas/degree of freedom ( $\mathrm{df}$ ) untuk penyebut atau df2 dengan rumus $\mathrm{df} 2=\mathrm{n}-\mathrm{k}$, dimana $\mathrm{k}$ adalah jumlah variabel (bebas + terikat) dan $\mathrm{n}$ adalah jumlah data. Dalam penelitian ini nilai $k=4$ dan $n=40$. Maka nilai df1 dalam penelitian ini adalah df1 $=4$ $-1=3$ dan df2 $=40-4=36$, sehingga dengan melihat nilai pada $F_{\text {tabel }}$ dengan df1 $=3$ dan df2 $=$ 36, diperoleh nilai $F_{\text {tabel }}$ sebesar 2,87.

Berdasarkan hasil uji F yang diperoleh pada tabel Anova di atas, dapat diketahui bahwa $F_{\text {hitung }}>F_{\text {tabel }}$ yaitu $(10,482>2,87)$, maka keputusannya adalah Ho ditolak dan H4 diterima. Artinya variabel persepsi (X1), sikap (X2) dan pengetahuan (X3) secara simultan atau bersama-sama berpengaruh terhadap minat menabung masyarakat pada Bank Aceh Syariah di Kecamatan Kota Kualasimpang $(\mathrm{Y})$.

\section{Uji Koefisien Determinasi (R2)}

Uji koefisien determinasi atau R2 bertujuan untuk mengetahui seberapa besar kemampuan variabel independen/bebas menjelaskan variabel dependen/terikat atau untuk mengetahui besar persentase variasi yang dijelaskan pada variabel bebas. Untuk mengetahui koefisien determinasi dapat dilihat pada nilai Adjusted $R$ Square pada uji regresi linear berganda. Berikut ini adalah hasil uji koefisien determinasi dengan SPSS versi 25 :

Tabel 9

Uji Koefisien Determinasi (R2) Model Summary

\begin{tabular}{cc|c|c|c} 
Model & $\mathrm{R}$ & R Square & $\begin{array}{c}\text { Adjusted R } \\
\text { Square }\end{array}$ & $\begin{array}{c}\text { Std. Error of } \\
\text { the Estimate }\end{array}$ \\
\hline 1 &, $683^{\mathrm{a}}$ &, 466 &, 422 & 1,894 \\
\hline
\end{tabular}

a. Predictors: (Constant), Pengetahuan(X3), Sikap(X2), Persepsi(X1)

b. Dependent Variable: Minat(Y)

Sumber Data Diolah: SPSS 25

Dari hasil uji Koefisien Determinasi pada Tabel. 4.21 diketahui bahwa angka R2 ( $R$ Square) sebesar 0,422, artinya variabel-variabel independen dalam penelitian ini yakni persepsi, sikap, dan pengetahuan masyarakat mampu menjelaskan variabel dependen yakni minat menabung 
pada Bank Aceh Syariah sebanyak 42,2\%. Sedangkan sisanya sebanyak 57,8\% dijelaskan oleh faktor lain di luar penelitian.

Sedangkan pada kolom R merupakan lambang yang menunjukkan koefisien korelasi (nilai yang menunjukkan kuat/tidaknya hubungan linier antara dua variabel). Dari hasil uji pada tabel di atas menunjukkan nilai koefisien korelasi (R) sebesar 0,683 mendekati nilai 1, artinya hubungan antara variabel-variabel bebas (persepsi, sikap, pengetahuan) dan variabel terikat (minat) sangat erat.

\section{KESIMPULAN}

Penelitian ini bertujuan untuk mengetahui pengaruh persepsi, sikap dan pengetahuan terhadap minat menabung masyarakat pada Bank Aceh Syariah di Kecamatan Kota Kualasimpang. Berdasarkan hasil analisis dan pembahasan data yang diuraikan pada bab sebelumnya, maka dapat diambil kesimpulan sebagai berikut:

1. Persepsi memiliki pengaruh yang Signifikan terhadap minat menabung masyarakat pada Bank Aceh Syariah di Kecamatan Kota Kualasimpang.

2. Sikap tidak memiliki pengaruh yang Signifikan terhadap minat menabung masyarakat pada Bank Aceh Syariah di Kecamatan Kota Kualasimpang.

3. Pengetahuan tidak memiliki pengaruh yang Signifikan terhadap minat menabung pada Bank Aceh Syariah di Kecamatan Kota Kualasimpang.

4. Terdapat pengaruh yang Signifikan secara simultan variabel persepsi (X1), sikap (X2) dan pengetahuan (X3) terhadap minat menabung $(Y)$ pada Bank Aceh Syariah di Kecamatan Kota Kualasimpang.

\section{REFERENSI}

Agus Arwani. (2015). Pengaruh Sikap Mahasiswa Muslim Terhadap Minat Pada Bank Syariah. Jurnal Penelitian Vol. 12, No. 1, 1-23.

ARIFAH, N. (2018). Pengaruh pengetahuan, kepercayaan dan sikap anggota terhadap keputusan menabung di bmt (Studi Kasus Di BMT Syamil Ampel Boyolali).

Arikunto, S. (1994). Evaluasi Pendidikan. Jakarta: Rineka Cipta.

Arikunto, Suharsimi. (2005). Manajemen Penelitian. Jakarta: Rineka Cipta.

Baba, Ricardo, and R. L. (2012). "Perceptions of Non-Muslims Towards Islamic Banking." Banker's Journal Malaysia, 10, no. 13, 12-16.

BPS Kabupaten Aceh Tamiang. (2019). Retrieved October 5, 2020, from 11140.2009 website: https://acehtamiangkab.bps.go.id/publication/2020/01/14/60f84c0d262976ff113e6638/st atistik-kecamatan-kota-kualasimpang-2019

Ghozali, I. (2011). Aplikasi Analisis Multivariate Dengan Program SPSS. Semarang: Universitas Diponegoro.

Ghozali, I. (2018). Aplikasi Analisis Multivatiate dengan Program IBM SPSS 25. Semarang: Universitas Dipenorogo.

Hikmah Ramadani. (2018). Analisis Pengaruh Pengetahuan, Sikap Dan Lingkungan Sosial Terhadap Keputusan Nasabah Menggunakan Produk Bank Syariah(Studi Kasus Bank BRI Syariah KCP 
Magelang). Journal of Economics. Retrieved from https://www.academia.edu/38922036/The_Integration_of_Technology_into_English_Lang uage_Teaching_The_Underlying_Significance_of_LMS_in_ESL_Teaching_despite_the_Ebb_ and_Flow_of_Implementation?email_work_card=viewpaper\%250Ahttps://doi.org/10.1155/2016/315980

Kanuk, S. dan. (2007). Perilaku Konsumen, (Edisi Ke; dialihbahasakan oleh Z. Kasip, Ed.).

Kotler, P. (2008). Manajemen Pemasaran. Jakarta: Indeks.

Mardiah, A., \& Putra, A. P. (2017). Analisis Minat Masyarakat Menabung Dibank Syariah (Studi Kasus di Kampung Paya Bedi Aceh Tamiang) Ainun Mardiah, Agung Pradhana Putra, Junaidi. Jurnal Ilmiah Mahasiswa.

Mowen \& John C. Michael Minor. (2001). Perilaku Konsumen (Jilid 1) Edisi Kelima. Jakarta: Erlangga.

Notoatmojo, S. (2007). Promosi Kesehatan dan Perilaku. Jakarta : Rineka Cipta.

OJK. (2017). Sejarah Perbankan Syariah. Retrieved August 31, 2020, from https://www.ojk.go.id/id/kanal/syariah/tentang-syariah/Pages/Sejarah-PerbankanSyariah.aspx

Priyatno, D. (2008). Mandiri Belajar SPSS. Yogyakarta: Mediacom.

Robbins, S. P. (2002). Prinsip - Prinsip Perilaku Organisasi (ed. 5). Jakarta: Erlangga.

Setiadi, N. J. (2003). Perilaku konsumen (Prenada Media, Ed.). Jakarta.

Sugiyono. (2012). Metode Penelitian Kuantitatif Kualitatif dan $R \& D$ (cet. 17). Bandung: Alfabeta. Sumarwan. (2011). Perilaku Konsumen Teori dan Penerapannya dalam Pemasaran (Ghalia Indonesia, Ed.). Bogor.

Wahab, A. R. S. \& M. A. (2004). Psikologi Suatu Pengantar dalam Perspektif Islam. Jakarta: Kencana, hlm. 262.

Wijayati, E. Y. (2019). Pengaruh Persepsi Dan Pengetahuan Terhadap Minat Menabung Di Bank Syariah Pada Masyarakat Dukuh Krajan Pulosari Jambon Ponorogo. 